\title{
Paulo Freire e a perspectiva dialética da educação como revelação do óbvio
}

\author{
Thalles Valente de Paiva ${ }^{1}$ \\ Orcid: https://orcid.org/0000-0001-5191-0723 \\ Lucia de Fatima Valente ${ }^{2}$ \\ Orcid: https://orcid.org/0000-0002-1228-5643
}

\begin{abstract}
Resumo
Freire costumava dizer que era um "educador das obviedades". O que isso quer dizer? A partir dessa pergunta este artigo analisará o "óbvio" em Paulo Freire, por um viés dialético. Tem como ponto de partida as obras "Pedagogia do Oprimido" e "A importância do ato de ler". O estudo discute a acumulação e a transferência na educação bancária; a dialética freiriana como esclarecimento do óbvio; o diálogo, fracassos e mudanças; o reconhecimento das exclusões; a dialética, a sintaxe popular e a questão política. Conclui-se que a dialética na educação é a revelação do "óbvio", o que significa dizer que o processo dialético tensiona a naturalidade hegemônica, quebrando o seu discurso estático, "socionatural", esclarecendo que seu semblante apolítico, no fundo, é político. Um educador das obviedades está disposto a argumentar, dialogar com os educandos a assertiva de que o mundo é movimento, transformação, e que a realidade social é uma construção humana.
\end{abstract}

Palavras-chave: Paulo Freire. Dialética da Educação. Política.

\begin{abstract}
Freire used to say he was an "educator of obviousness". What does that mean? Based on this question this article aims to analyze the "obvious" in Paulo Freire by means of a dialectical bias. This study has the works "Pedagogy of the Opressed" as well as "The importance of the act of reading" as its starting point. It also discusses the accumulation along with the transference in the bancary education; the Freirean dialectics as the enlightenment of the obvious; the dialogue; failures and changes; the recognition of the exclusions; the dialectic within the popular syntax and the political issue. The article concludes the dialectic in education is the revelation of the "obvious" which means that the dialectical process tensions the hegemonic naturality, breaking the static discourse, clarifying that their apolitical aspect is in fact, political. An educator of obviousness is always willing to discuss and uses assertive communication with the learners that the world is movement, transformation and that social reality is a human construction.
\end{abstract}

Keywords: Paulo Freire. Educational Dialectics. Politics.

\footnotetext{
${ }^{1}$ Doutorando em Educação no Programa de Pós-graduação da Faculdade de Educação (PPGED), na linha de História e Historiografia. Graduado em História e Mestre em História Social na área de Estética e Hermenêutica, pela mesma Universidade. E-mail: thallesvalentep@hotmail.com

${ }^{2}$ Doutora e Mestre em Educação pela Universidade Federal de Uberlândia. Professora da Faculdade de Educação da Universidade Federal de Uberlândia, com atuação na graduação, no curso de Pedagogia e na Pósgraduação, no Programa de Pós-graduação da Faculdade de Educação (PPGED), na Linha Estado, Política e Gestão da Educação. E-mail: valentelucia@yahoo.com.br
} 


\section{Introdução}

Paulo Freire se definia, por vezes, como um "educador das obviedades". O apelo ao "óbvio" é pela razão de que nem sempre a consciência está atenta às "obviedades" do "óbvio". Em seu belo poema Canção óbvia (1971), escrito no exílio na Suíça, o educador narra irregularidades e contrariedades da consciência em sintetizar a experiência no entendimento:

[...] Por isto, enquanto te espero trabalharei os campos e conversarei com os homens. Suarei meu corpo, que o sol queimará, minhas mãos ficarão calejadas, meus pés aprenderão o mistério dos caminhos, meus ouvidos ouvirão mais, meus olhos verão o que antes não viam, enquanto esperarei por ti (FREIRE, 1971, p.05, grifo nosso).

Em ato, na ação trabalho, entre a cultura e a relação social, não é possível à consciência tomar conhecimento de sua relação, seu posicionamento ao mundo. Esse déficit diz respeito à alienação do sujeito engajado à causa, somente a posteriori, no fim do acontecimento, por meio de um conhecimento que retroage o passado, esse toma consciência daquilo que seus olhos e ouvidos não virão e ouvirão. Esse, talvez, seja o grande insight do poema de Freire, a passagem do ser-aí (acabado) ao ser-para-si (para si mesmo); na passagem dos acontecimentos para "espera de ti", as coisas não se apresentam mais como uma dispersão, mas como "síntese", isto é, a multiplicidade das propriedades reais (Suarei meu corpo, que o sol queimará, minhas mãos ficarão calejadas), é suprimida pela razão (meus pés aprenderão o mistério dos caminhos...). Podemos dizer que está aí uma reviravolta do entendimento ao "óbvio".

É às vezes quando a gente se aproxima da obviedade e toma a obviedade na mão, e dá uma rachadura na obviedade, e tenta entrar na obviedade para vê-la desde dentro e de dentro e por dentro (isto é, ver o óbvio de dentro e de dentro dele olhar para fora), é que a gente vê mesmo que nem sempre o óbvio é tão óbvio (FREIRE, 1985, p.92).

Adentrar e tomar certa distância para analisar as "obviedades" não reconhecidas como "óbvias", é reconhecer o "óbvio", contextualizando-o nas contradições do presente. Freire (1985), em meio às lembranças do tempo que ficou exilado pela ditadura militar brasileira, relata que era "óbvia" a assertiva que a educação não é neutra. Dizia isso com a maior naturalidade em suas palestras na Alemanha e na Inglaterra, tanto que não cuidava de justificar e contextualizar essa sentença, já que era "óbvia” demais. O espanto aconteceu quando o auditório se incomodou e contestou aquilo que era tomado como "óbvio" para Freire.

É certo que se analisarmos a primeira camada da "obviedade", esta poderá aparecer na assertiva "clichê" nominalista na qual "o que é obvio para um, não é para outro", o que indicaria que o "óbvio" atua como um significante que requisita uma significação específica a um certo contexto de acordo com os limites, possibilidades e particularidades do sujeito à realidade. No entanto, se essa fosse certeza do enunciado de Freire, apenas os formalismos, ou até mesmo o conteúdo da obviedade burguesa, com certeza o educador não marcaria o pensamento educacional brasileiro.

\section{Acumulação e transferência: o sonho da Educação bancária.}

Uma das singularidades de A pedagogia do Oprimido (1987) foi assinalar um "óbvio" não reconhecido pela educação burguesa tradicional. Freire (1987) não apenas se ocupou com 
a forma da educação (cada perspectiva tem uma maneira de criar um método para educação), mas em problematizar o conteúdo adotado pelo "ponto de vista" da perspectiva e o que esta excluiu de sua estrutura. Ora, um dos marcos dessa obra não foi que apenas friccionando a forma e conteúdo do modelo burguês é que aparece o "óbvio" de sua estrutura organizacional?

Sabemos que a realidade burguesa, em seu vir a ser, opera por uma fantasia de acumulação, transferência e circulação abstrata infinita de capital. Esse movimento não se restringe apenas a uma particularidade específica da realidade; ao contrário, perpassa o "Todo" da realidade social. A educação, como parte dessa realidade, está constantemente sendo castrada pelas demandas da ideologia dominante. Todavia, devemos estar atentos que a circulação ideológica não ronda apenas as especificidades objetivas (instituições, redes privadas etc.), pois esta, também, contrasta com as subjetividades dos sujeitos. É por essa razão que podemos observar a circulação ideológica em desejos culturais, em imaginários sociais, em sonhos de progresso, em projetos tecnológicos científicos e em representações artísticas. Na série En L'An 2000 ("No Ano 2000", em francês), há imagens futuristas desenhadas entre os anos 1899 a 1910, em caixas de cigarros e de charutos por vários artistas, incluindo Jean-Marc Côte, que imaginaram como seria o futuro nos anos 2000. Em uma delas há uma imagem marcante de como seria o progresso da educação. Em at School ${ }^{4}$, um professor deposita uma abundância de livros em uma máquina grande cujos fios estão conectados aos capacetes, repousados na cabeça dos alunos que, inertes, apenas recebem o saber passivamente. Quem sabe essa imagem não represente, retroativamente, uma anedota do sonho quimérico da educação tradicional?

Essa imagem futurista não está tão distante de nós. É claro que não é um espalhafatoso capacete repousado na cabeça de alguém, e sim um gadget "modesto", mas, infinitamente mais pretensioso que os capacetes de at School. O "SixthSense" não é uma tecnologia exclusiva para a educação, mas pode muito bem ser usada na educação, assim como os computadores e celulares. O aparelho é uma "interface gestual" e portátil desenvolvida por Pranav Mistry, do grupo de interfaces fluidas do MIT Media Lab ${ }^{5}$. O hardware é um equipamento que podemos vestir, dispõe de uma pequena câmera pendurada no pescoço, um projetor portátil e um espelho, todos conectados a um smartphone. O usuário interage segurando objetos, ou gesticula apontando com as mãos. O programa lê e processa os dados e busca na internet as informações e, na sequência, projeta essas informações em qualquer superfície física. Por exemplo, professores e alunos pegam um livro didático e, no mesmo instante, são projetadas críticas de leitores e de especialistas, classificações, orientações do Ministério da Educação etc., sendo que todas as informações estão com hipertextos, informando os usuários de maneira quase ilimitada.

Não apenas a sala de aula, mas o mundo inteiro se tornará uma "superfície multitoque" e a internet será utilizada continuamente para fornecer dados adicionais que permitam nossa orientação. Todas as coisas com as quais interagimos são projetadas reproduzindo informações e isso inclui pessoas também. Tudo vai ser revelado continuamente, emanando sua própria interpretação. $\mathrm{O}$ que parece ser uma revolução, o rompimento das experiências ordinárias em sala de aula, e o ser e estar no mundo, todavia representam o que já acontecia em nossa realidade. Como disse Žižek (2017), a nossa experiência de realidade é, na teoria lacaniana, regida pelo "grande Outro" (a espessa tecitura simbólica de saberes, conhecimentos, expectativas, preconceitos etc.) que, a todo o momento preenche as lacunas de nossa percepção (ŽIŽEK, 2017, p.230). Quando pensamos no formato da escola

\footnotetext{
${ }^{3}$ Para mais ver https://publicdomainreview.org/collection/a-19th-century-vision-of-the-year-2000

${ }^{4}$ A gravura por ser vista em https://pt.m.wikipedia.org/wiki/Ficheiro:France_in_XXI_Century._School.jpg

5 Para mais informações https://www.pranavmistry.com/archived/projects/sixthsense/
} 
hegemônica, esta não "vê" e "organiza" sua metodologia "projetando" as diretrizes e demandas da realidade burguesa?

Em uma análise breve de seu funcionamento educacional, primeiramente em sua forma, a educação deveria se submeter a um sofisticado mecanismo que ampliasse a transferência e a captação do saber, diminuindo a incidência de possíveis erros (acasos, "pontos de vistas" conflitantes, falhas cognitivas dos educandos, cultura, subjetivismos etc.); e, segundo, o conteúdo, acumulação e transferência do saber são princípios diretos e apolíticos, o ensinar e o aprender "perderiam" sua relação Real traumática (a política, partidarismos, contradições e antagonismos), e seria, simplesmente, um compartilhamento "imparcial" de dados, sem as "contaminações" subjetivas de educadores e educando. Essa é a razão que tanto os capacetes de at School, como o gadget de "SixthSense", são típicos casos de tecnologia a serviço da ideologia. Esses aparelhos materializam os mecanismos ideológicos como certo e errado, sobredeterminando saberes, percepções e interações sociais e educacionais.

Sob o "ponto de vista" freiriano, essa estrutura só funciona com o princípio a priori que aprender é guardar informações, os educandos são repositórios, não sujeitos que dialogam com o saber, mas objetos nos quais se depositam informações sem passar pelo processo de problematização. O desenho at School e o "SixthSense" podem ser interessantes exemplos para pensarmos, de maneira hiperbólica, o que é uma educação presa em uma transferência linear e passiva, em que o fim máximo do saber é apenas acumular, guardar e replicar, repetindo-se em um processo sem fim. Foi contra essa abstração quimérica que Freire lutou, qual seja, a educação cujo modus operandi é a ação dissertadora do mestre que deposita o saber naqueles que nada sabem. Freire (1987) a conceituou de educação bancária.

Eis aí a concepção "bancária” da educação em que a única margem de ação que se oferece aos educandos é a de receberem os depósitos, guardá-los e arquivá-los, margem para serem colecionadores ou fichadores das coisas que arquivam. No fundo, porém, os grandes arquivados são os homens, nesta (na melhor das hipóteses) equivocada concepção "bancária" da educação. Arquivados porque fora da busca, fora da práxis, os homens não podem ser. Educador e educandos se arquivam na medida em que nesta destorcida visão da educação, não há criatividade, não há transformação, não há saber. (FREIRE,1987, p.37 a 38)

Nesta concepção é o educador que pensa e os educandos os pensados; o educador é que tem a Voz, o domínio da palavra, e os educandos somente os ouvidos, a submissão; o educador é autoridade mestre, ele é que organiza a realidade da sala de aula à qual os alunos devem, prontamente, se adaptar (FREIRE, 1987, p.38). O que a forma e conteúdo desta estrutura reforçam é que o sujeito deste processo é o mestre que cria e participa; ele é o sujeito pensante, o artista escultor que modela os "alunos", enquanto os educandos são simplesmente objetos conformados que se adaptam às ferramentas de seu mestre artesão. Ao contrário, dizia Freire:

É preciso, sobretudo, e aí já vai um destes saberes indispensáveis, que o formando, desde o princípio mesmo de sua experiência formadora, assumindo-se como sujeito também da produção do saber, se convença definitivamente de que ensinar não é transferir conhecimento, mas criar as possibilidades para a sua produção ou a sua construção (FREIRE,2002, p.13).

O "óbvio", não reconhecido pelo modelo bancário, foi ignorar que o processo de aprender e ensinar não é uma "doação" na qual existe um sujeito puro que deposita o saber (como nos bancos) naqueles que não sabem, mas, um diálogo radical que contextualiza o saber na realidade do educando. O "óbvio" mantido nas aparências de "naturalidade", pela educação bancária, está a serviço do mundo burguês e a educação simplesmente deve simular 
o normativo, as demandas da estrutura dominante. Assim, esse "óbvio" tenta, a todo custo, excluir da realidade o conteúdo partidário traumático (A quem está endereçada? Qual é sua função política?): a educação não é neutra.

\section{A dialética freiriana como esclarecimento do "óbvio"}

Quando pesquisamos a palavra "óbvio" no dicionário ${ }^{6}$, como adjetivo, consta que: (1) o que pode ser apreendido, captado ou pressentido por intuição; que não se pode pôr em dúvida; axiomático, evidente, incontestável. Ex: "Que esta seria a sua reação à demissão, era óbvio."; (2) Na forma de substantivo, óbvio significa aquilo que é evidente. Ex: "Por vezes é difícil enxergar o óbvio.". Ou seja, podemos dizer que o "óbvio" é aquilo que é evidente, mas, paradoxalmente difícil de enxergar. Talvez, a única possibilidade de ressignificar essa contradição seja pela práxis dialógico-dialética.

É possível observar, em certos mecanismos ideológicos disseminados pela "educação bancária", a assertiva que o ser não é sujeito para um Outro, mas um indivíduo autônomo, consciente, livre e racional. Por ter esses predicativos intrínsecos à sua "natureza", o indivíduo é independente para fazer escolhas políticas e religiosas, e ainda comercializar e vender sua força de trabalho. No entanto, para a "educação crítica", o ser está sujeito a um Outro. Ao contrário de ter uma relação direta e mediata com o mundo, de ser o sujeito abstrato cognoscente, que age de maneira autônoma examinando a realidade e fazendo escolhas livres e racionais, ele exerce suas atividades, contrastando-as dentro de determinados conjuntos de relações sociais. O sujeito experimenta a realidade de maneira "práticasensível", de forma imediata (experiência sensível) intui e reage a ela, criando representações das coisas em sua volta, elaborando um sistema de noções correlativas ao que ele capta dos fenômenos da realidade.

Por essa razão é que, como disserta Kosik (1976), na relação cotidiana nós espontaneamente não focamos em todos os aspectos da realidade pois apenas percebemos certos traços da realidade, alguns mais ou menos nítidos, e outros nem tanto. No entanto, mesmo não captada a "totalidade", ela ainda fica registrada de fundo (como no "grande Outro" lacaniano); esta fica como um "horizonte" obscurecido, indeterminado para o sujeito, inconsciente para uma consciência que se encontra em estado de "ingenuidade".

O "óbvio", portanto, não está apenas na condição da percepção subjetiva, mas no seu sentido ao Outro. O "óbvio" da educação bancária está estruturado na práxis burguesa na qual uma educação tem como finalidade servir a megalômana abstração capitalista, dividindo aqueles que sabem e não sabem, gerindo e progredindo na divisão de classes. A educação crítica, por outro lado, encaminhará na práxis de adentrar as "obviedades" da realidade dos estudantes, na qual o educador aprenderá junto como os educandos, mas, depois se afasta, tomando certa distância da cultura dos estudantes para avaliar, problematizar a realidade junto com eles para que, no final, desmistifiquem as ideologias e aparatos de opressão, analisando as contradições e os antagonismos que friccionam a realidade.

\section{Diálogo, fracassos e mudança}

O diálogo é a nossa fundamental ferramenta para construirmos as mediações que retroagem, pelo movimento dialético, aquilo que antes estava obscuro, e, assim, transpareça o "óbvio", e, como dizia Freire (1971), ver aquilo que nossos olhos antes não viam. A acepção da dialética na educação é a postura de estar aberta às contingências, de saber que as coisas

\footnotetext{
${ }^{6}$ Ver https://www.dicio.com.br/obvio/
} 
mudam, que a percepção dos acontecimentos não é "óbvia" à primeira vista, mas pode ser entendida e ressignificada por meio da mediação pós acontecimento. Essa acepção ainda pressupõe que a alienação, os equívocos, as falhas e a falta de entender aquilo que parece "óbvio" não estão ligados intrinsecamente aos limites de estudantes e educadores, mas que a realidade é "em si" contraditória e está em permanente transformação. Além disso, ressalta que o universo da educação faz parte do processo dialético de aprender e ensinar e adentrar esse movimento de contradições.

Do "ponto de vista" moderno Heráclito foi o pensador dialético mais radical da Grécia antiga. Em Fragmentos (sobre a natureza), temos a passagem mais famosa do pensador, no fragmento $n^{\circ}$ 91: "Não se pode entrar duas vezes no mesmo rio (HERÁCLITO,1991, p.83)." Não apenas é impossível banhar-se em águas passadas, como o ser que se banhou outrora já não é o mesmo. Ora, o mesmo não ocorre no processo de aprender e ensinar? O passe da construção do conhecimento entre educador e educando esclarece que no final da jornada os sujeitos do processo já não são os mesmos - agora se encontram transformados pelo processo de construção do saber. Talvez seja por isso que Freire (2002) dizia que ensinar e aprender são uma aventura criativa e transformadora.

Entretanto, podemos objetar essa assertiva considerando-a como um "romantismo ingênuo", ou que é uma visão mecanicista, teológica de ensino; devaneios de um louco sonhador que não enxerga o "óbvio", que se sujeita a um semblante enganoso, utópico, etc. É óbvio que o saber pode provocar todos os tipos de impulsos subjetivos: emancipatórios para subjetividades abertas ao engajamento transformador; prudência cética, subjetividades que temem em cair em aparências de falsas emancipações; fatalista, que crê não existirem maneiras de transformar a realidade; entre outros. Todavia, o que Freire sempre defendeu é que além da realidade ser contingente, ela é criada e transformada no tempo, e mais, está sempre contrastando, em "curtos-circuitos" com o sujeito. Assim, ao engajarmos pela via dialética da educação (subjetividade em tensão com a objetividade), o futuro se apresentará como uma instância aberta, pois "O mundo não é. O mundo está sendo (FREIRE, 2002, p. 39 a 40).”.

Quando estamos engajados em uma jornada de aprender e ensinar, nos lançamos à abertura da contingência. Expostos à lacuna do nosso ser (em sua incompletude), corremos o risco de acertar ou, simplesmente errar o nosso alvo. Se, certa proposta educativa (que se movimenta na tensão entre subjetividade e objetividade) fracassar, ou seja, revelar que o caminho metodológico escolhido se manifestou como insuficiente para as demandas do aprendizado de um determinado lugar, esta é a síntese do processo, a assertiva que as especificidades da forma/conteúdo, ligadas a determinado contexto, chegou ao seu limite. Nessa situação não deveríamos cair na lamúria, visto que isso faz parte do processo dialético de aprender e ensinar. Essa falha demonstra que devemos reconhecer que esse caminho pedagógico chegou ao seu limite e esta é a hora de transformá-lo, ou mudar os rumos.

Portanto, seria ingenuidade cairmos nas tentações fatalistas, visto que os limites e o fracasso do método aparecem apenas no final do processo, porque somente após o diálogo metodológico entre educador e estudantes, em contraste com a sua realidade, é que estes tomam a consciência que aquele conteúdo não foi suficiente para aquela situação. Por essa razão é que os fracassos e erros são importantes para o processo de aprendizagem. Em primeiro lugar devemos tentar criar um "método" e, durante o fluxo da práxis, caso, por algumas inconsistências, esta fracasse, somente após a tentativa da criação do evento pedagógico, a posteriori, é que retroagimos os significados dos caminhos passados e reconhecemos o "óbvio" (seus limites e fracassos), e partimos para outro caminho.

Isso demonstra que a mudança também se manifesta nos fracassos e nos erros. Após o conteúdo fracassar, uma nova forma anuncia os equívocos e os restos que o conteúdo passado deixou de fora. Em outras palavras, o que ocorre na jornada de aprender e ensinar, no fluxo 
contingente do saber é o fato de que os sujeitos se transformam na medida em que as verdades lhe tocam. Até o mais cético dos estudantes não pode negar que ocorreu um processo do qual ele participou, e, ao fim, a jornada lhe demanda uma posição e uma significação do acontecimento.

\section{As exclusões necessitam de reconhecimento}

Segundo Žižek (2013), no processo dialético existe uma lacuna transcendental latente entre forma e conteúdo e é por isso que deveríamos prestar atenção ao conteúdo, ou a princípios estruturais, ou seja, distinguir entre os elementos e os lugares formais que tais elementos ocupam. Vale salientar que só atingimos uma análise propriamente dialética quando concebemos o procedimento formal, não como expressão de certo aspecto do conteúdo, mas como se marcasse aquilo que o conteúdo excluiu (ŽIŽEK, 2013, p.174). Voltando à jornada do aprendizado, se quisermos reconstruir o "todo" daquela situação, devemos ir além do conteúdo construído historicamente (entre educador e os educandos) e analisar as características formais que foram substituídas, excluídas daquele conteúdo e, assim, com uma nova forma metodológica ir em direção a um novo conteúdo que expresse aquilo que estava de fora, assim criando um processo de aprendizado que será sempre "inacabado" justamente porque não apenas a jornada de aprender e ensinar não tem fim, mas porque, em Freire, o ser é inconcluso (FREIRE, 2002, p. 26).

Esse inacabamento permite que o ser se transforme durante o processo, que mude, não se fixando a um conteúdo estático e imutável. Por conseguinte, é estranho para o pensamento dialético moderno uma "síntese" que concilie as contradições, a fim de harmonizar a forma e o conteúdo, acabando com as tensões, fechando o movimento da realidade, pondo o fim. $\mathrm{Na}$ verdade, o que a "síntese" faz é demonstrar as contradições, os antagonismos e as exclusões. O que o processo dialético manifesta é o Real traumático que corta a forma e conteúdo, aquilo que, de uma certa maneira, ainda não foi mediado e reconhecido.

Talvez uma maneira didática de visualizarmos isso seja no lendário chiste judaico da União Soviética. Rabinovitch se apresenta na Emigração em Moscou e diz que quer emigrar. O funcionário do escritório, encabulado, pergunta o motivo. Rabinovitch, ávido, responde: "Há duas razões. A primeira é que tenho medo de que o poder comunista na União Soviética venha a desmoronar e que, após a chegada da reação ao poder, todos os erros do socialismo sejam imputados aos judeus, os bodes expiatórios habituais. Então, haveria pogroms [perseguição étnica] novamente..." Rapidamente o funcionário o interrompe: "Mas isso é um absurdo - o poder comunista na União Soviética é invencível, durará para sempre e nada pode mudar na União Soviética..." De forma irônica, mas tranquila: "Essa é a segunda razão."

O interessante desse chiste é que a resolução dele é apenas performativa porque a negação ainda persiste, mas, revertida pelo "ponto de vista" de um laço que performa a tentativa de um novo "reconhecimento" ao Outro. (1) No polo positivo (tese) temos a assertiva que Rabinovitch quer sair e sua postura é uma rebeldia que tensiona o ethos soviético, demasiadamente burocrático; (2) No polo negativo (antítese), o oficial, a mando da lei, o nega, afirmando ser o conteúdo soviético indestrutível, e nunca perecerá; (3) A réplica é a "negação da negação" (síntese), retroage a afirmativa transformando-se em seu contrário, uma transformação formal. De outro modo, o que se observa é apenas uma reviravolta de perspectiva na qual o fracasso retorna em uma nova forma que pede "reconhecimento" no ordenamento do conteúdo do Outro.

Acreditamos que é assim que deveríamos pensar a dialética do aprender e ensinar em Freire. A fim de ilustração, podemos pensar em uma cena típica de sala de aula, muito clichê por sinal. Um estudante "arteiro", que não presta atenção às aulas, não estuda e não faz suas atividades, conversa o tempo todo com seus colegas, solta gargalhadas e tem orgulho de suas 
bagunças. O professor, estressado, o adverte dizendo que sala de aula não é um circo e o obriga a estudar. O aluno, irritado, diz: “- Eu não quero aprender! Isso não tem sentido pra mim! Eu não acho que tua aula pode me ajudar em alguma coisa e muito menos na minha vida!". Na sequência desse enunciado, o professor tenta mediar essa tensão apelando à positividade do saber mestre: “- Bem, se você não quer aprender, você não será ninguém na vida! Lembre-se que a única forma de você mudar sua vida é estudando. Você não quer ser reconhecido!? Ser respeitado pelos seus familiares e pela sociedade!? Portanto, comporte-se e estude!" O estudante, contraditoriamente, diz: "- Eu sei que a educação é importante e também sei que só com "ela" viramos gente e blá, blá, blá. Mas, mesmo assim, eu não quero estudar!" Ora, essa situação não tem o mesmo conteúdo que a história de Rabinovitch?

Se observarmos atentamente, encontraremos uma reviravolta nesse exemplo. $O$ estudante contorna a "negação" do professor como uma "negação da negação" ("Eu sei que a educação é importante, mas, mesmo assim, eu não quero estudar!"), ou seja, aí encontramos um Real que ainda não foi mediado, reconhecido pelo Outro. Deveríamos, assim como o chiste Rabinovitch, nos perguntar se aquele educando é reconhecido (sua cultura, classe, etnia, gênero etc.) pela positividade hegemônica e pelo método educacional utilizado. Em poucas palavras, deveríamos questionar, problematizar qual é a situação contraditória em que esse estudante se encontra (problemas familiares, financeiros, psíquicos, vícios, violências, etc.) para ver as possíveis saídas para esse problema, não esquecendo, é claro, dos limites reais da Escola. Ao contrário de cedermos ingenuamente ao subjetivismo, a ferramenta da dialética nos auxilia a analisar as contradições e os antagonismos que impedem, objetiva e subjetivamente, a sublimação do estudante ao saber. Nesse contexto perguntamos: Quais são seus empecilhos? Por que o aluno não quer estudar? Longe da dialética ser uma ferramenta que alinha educadores e educandos a uma jornada linear, harmônica e segura, essa é uma ferramenta que nos auxilia a posteriori do evento, ou seja, a dialética nos auxilia analisar o processo do método pedagógico, suas possibilidades emancipatórias, suas exclusões e seus limites. E, claro, esclarece o "óbvio" da organização social.

Como educadores, deveríamos sempre estar atentos às especificidades de cada situação e de cada lugar social. Freire (2001) dizia que certos educadores que se autointitulam de progressistas, embora mantenham as aparências de professores engajados (mantendo uma retórica sofisticada em favor aos oprimidos), sua prática, no entanto, é simplesmente retrógrada por não se atentarem às reais necessidades dos educandos, tratando-os como puros recipientes de sua sabedoria. Em outros casos se comportam na forma de "caráter basista", em que a prática educacional, em áreas populares, é via da autentificação do "passaporte militante", em que ocorre simplesmente uma transferência academicista, ou intelectualista, sem contextualizá-la àquele lugar. Freire sempre foi um crítico severo à demasiada distância do discurso do educador e sua prática, não para buscar uma pureza prática, ou muito menos, de maneira vulgar, dizer que existe uma diferença excessiva entre teoria e prática, mas visando atentar-se ao movimento dialético entre discurso e a prática:

$\mathrm{Na}$ verdade, o que devemos buscar é a unidade dialética, contraditória, entre teoria e prática, jamais sua dicotomia. A questão da linguagem, no fundo, uma questão de classe, é igualmente outro ponto em que pode emperrar a prática educativa progressista. Um educador progressista que não seja sensível à linguagem popular, que não busque intimidade com o uso das metáforas, das parábolas no meio popular, não pode comunicar-se com os educandos, perde a eficiência, é incompetente (FREIRE, 2001, p.29).

\section{Dialética e sintaxe popular}


O adentrar à linguagem do lugar é se engajar na sintaxe popular, na estrutura que organiza o pensamento daqueles sujeitos. $\mathrm{O}$ educador deve adentrar esse universo, não negando o seu saber acadêmico, o que levaria a uma postura ilusória populista. Trata-se, no entanto, de um movimento de uma mediação ética que reconheça o outro e suas especificidades e que, ao mesmo tempo em que contrasta, faça um "curto-circuito" com aquele lugar. Assim, o instrumento acadêmico não deve ser diluído mas deve estar a serviço dos envolvidos no processo de aprender e ensinar e o saber necessita ser um instrumento para a liberdade que esclareça o "óbvio" ainda não compreendido.

Uma fábula popular compartilhada no sul e na zona da mata de Minas Gerais é o fenômeno dos "grãos Filipe" (ou Felipe). Em época de frutificação das cafeeiras, em meio ao mar verde das lavouras, é possível encontrar um grão maior composto por dois ou até mesmo quatro frutos que se formaram juntos. O trabalhador que se deparasse com os "grãos Filipe" teria ali achado um tesouro, já que, para a forma do mito desse lugar, o encontro com os grãos proporcionava uma relação mítica entre o felizardo e a comunidade. Bastaria dar os grãos a alguém e logo a "substância" dos grãos dialeticamente transmutaria seus significantes em relação ao receptor da mensagem. Por exemplo, um rapaz pode por meio desses grãos, criar um laço de amor ao entregá-los à sua amada, fazendo um pedido de casamento; em casos de mágoas e ressentimentos, uma amizade pode ser reatada pela mística do "café Filipe"; ou uma criança que, ao encontrar esse tesouro, pode entregar os grãos a um adulto e pedir um presente.

Podemos até imaginar uma escola rural para crianças, jovens e adultos, em uma pequena cidade, que faz divisa com vários vilarejos e comunidades rurais. Lá, em uma minúscula sala de aula, encontramos um educador que está imerso nas vivências culturais dessas comunidades. De maneira "óbvia", podemos nos perguntar como um educador poderia analisar esse mito cultural. E mais, a partir desse fenômeno "Filipe", como ele poderia criar um "método" educacional, a partir das possibilidades sociais reais, que, além de dialogar com esse universo, fricciona-o à problematização?

Em relação às possibilidades de realidade e de escolha, quem sabe não possam aparecer várias ferramentas que guiem esse professor em sua jornada pelo saber... Porventura, se optasse por uma perceptiva "bancária" (hegemônica), o fenômeno cultural "Felipe" apareceria como uma coisa irrelevante, tanto em sua forma, como em seu conteúdo. Os grãos seriam apenas um episódio irrisório, sem sentido objetivo, um culturalismo vulgar que não interfere na forma positiva em relação ao conteúdo do mercado de café. Enquanto esse fenômeno não for contrastado com a positividade da hegemonia, essa atividade será "reconhecida" como uma inofensiva e fantasiosa fábula popular.

Esse caso é interessante para pensarmos o alcance do "político" na educação bancária. No universo liberal tradicional (burguês), a esfera do político está restrita, como analisa Skinner em referência ao âmbito das decisões administrativas e de negócios públicos. Nesta perspectiva estão fora não apenas as "relações íntimas" (gênero e sexualidade), mas, também, a cultura, arte, a ciência e, até mesmo a economia capitalista (que é dada como natural) todas essas categorias são consideradas como "apolíticas". (SKINNER, 1988). Mas, caso uma dessas esferas interfira na "naturalidade" da organização social, os setores hegemônicos administrativos sempre tomam providências. Voltando para nosso exemplo, se o fenômeno "grãos Filipe" transparecesse seu poder transformativo, e se manifestasse na forma incômoda, na expressão e na práxis de seu conteúdo negativo (por exemplo, se esse costume diminuísse a produtividade de café), os setores hegemônicos entrariam com força para destruir esse conteúdo cultural, uma vez que este contaminaria a episteme mercadológica.

Poderíamos imaginar os grandes produtores de café tomando as providências coercitivas, tanto nas suas propriedades, quanto na política da região, na tentativa de excluir rapidamente esse costume. Não seria estranho pensar na pressão que esse educador sofreria 
por parte do poder hegemônico, exigindo uma educação que desmitificasse essa anomalia, para que tudo voltasse ao "normal". Não é de se estranhar que a episteme bancária seja exclusivamente um ajustamento das demandas dominantes, pois, qualquer relação cultural só tem importância à medida que ajuda ou impede as diretrizes hegemônicas. A adaptação é o norte, como diria Freire (1987) e a educação bancária é um mecanismo que ajusta o ser à demanda do Outro.

O professor pode utilizar ferramentas como o realismo científico, a fim de "desalienar" seus perdidos "alunos" imersos no formalismo mítico popular. E dizer que a formação de frutos Filipe está relacionada à duplicação dos pistilos (pistilo é o conjunto que forma o órgão feminino da flor), comum também em outras espécies, em geral associada à falta de água. No caso da planta que dá a maior parte de filipes, o que é raro, pode ter ocorrido uma mutação. É "obvio" que um especialista entende a verdade do fruto café, em suas especificidades fenomênicas, além de estar imerso no progresso da literatura científica sobre o tema. No entanto, isso não é suficiente para analisar essa situação em seu "Todo". Não que não haja verdade nas palavras de engenheiro agrônomo; pelo contrário, é que nessa situação devemos ir além do realismo naturalista dos "grãos Filipe" e também observar seu "semblante" cultural.

É certo que a realidade natural contrasta com a realidade humana; porém, em perspectiva dialética, como dissertou Kosik (1976), o sujeito humano é produtor de sua realidade.

\begin{abstract}
O mundo real, oculto pela pseudoconcreticidade, apesar de nela se manifestar, não é o mundo das condições reais em oposição às condições irreais, tampouco o mundo da transcendência em oposição à ilusão subjetiva; é o mundo da praxis humana. É a compreensão da realidade humano-social como unidade de produção e produto, de sujeito e objeto, de gênese e estrutura. O mundo real não é, portanto, um mundo de objetos "reais" fixados, que sob o seu aspecto fetichizado levem uma existência transcendente como uma variante naturalisticamente entendida das idéias platônicas; ao invés, é um mundo em que as coisas, as relações e os significados são considerados como produtos do homem social, e o próprio homem se revela como sujeito real do mundo social (KOSIK, 1976, p.23).
\end{abstract}

A explicação realista naturalista concentra-se apenas no conteúdo verdadeiro e universal do fruto café (o caráter natural dos grãos gêmeos); no entanto, somente isso não é suficiente porque não é possível observar o produto da linguagem social, os "grãos Filipe". Aqui não estamos caindo no nominalismo "pós-moderno" em que a problemática dos grãos seria uma redução a problemas nominais a diferentes termos: o fenômeno "Filipe" seria simplesmente o uso cultural da linguagem sem contraste político. O político não seria cortado por um Real que corta a realidade (antagonismos de classes, por exemplo), mas, a assertiva nominalista é que cada grupo usa o sentido de político em sentidos diferentes. No entanto, nenhuma dessas perspectivas consegue explicar o "em si" desse fenômeno, o "óbvio" ainda não reconhecido. Qual é ou o que é esse óbvio? Ora, o que um educador crítico dialético (freiriano) faria diante dessa situação? Como analisaria o fenômeno "Filipe"? Como ele criaria um "método" de ensino?

Primeiro ele partiria da realidade daqueles trabalhadores dialogando, aprendendo junto com eles, na tentativa de adentrar o seu universo cultural. Portanto, sua primeira tarefa é de se familiarizar com a estrutura essa sintaxe popular, como se estrutura o pensamento, a linguagem, a concretude, apreensão do concreto, a abstração e o conhecimento desse lugar. Depois dessa entrada o formalismo não é suficiente para a proposta da educação crítica e deve-se avançar para a crítica do conteúdo: o que os "grãos Felipe" dizem sobre essa organização social? Essa prática cultural é exclusiva da classe trabalhadora? Se sim, por que os patrões, os grandes fazendeiros e as elites da comunidade não se encantam com o 
misticismo dos "grãos Filipe"? Enfim, o que os "grãos Filipe" têm a nos dizer sobre essa forma de organização social?

Esquematizando os "grãos Filipe" ao "método Paulo Freire", podemos dizer que este passaria pelo movimento da dialética entre o "Universal" (o Outro acadêmico) e o particular (as especificidades do lugar), entrelaçadas pelas formas das interdisciplinaridades. Como nos ensina Gadotti (1996), seriam em três momentos:

$1^{\circ}$ ) A investigação temática, educandos e educadores procuram, no universo vocabular (a sintaxe popular) do estudante, as especificidades que contrastam com sua realidade vivida. No caso de comunidades de cafeicultores, como nosso exemplo, os "grãos Filipe" seriam uma das portas que possibilitariam adentrarmos os temas centrais das biografias dos estudantes.

$2^{\circ}$ ) A tematização, é o "curto-circuito" ao Outro e a mítica dos "grãos Felipe" seria codificada e decodificada. Educador e educandos buscariam as significações desse fenômeno (em sua forma bio, histórica, política e cultural), o seu significado social. Esse movimento significa a tomada de consciência e a educação, em sua forma crítica, estimularia a problematização: Quem sou eu para o Outro (subjetiva)? Qual é minha função social (objetiva)? Por que minha realidade é assim? No que se refere à dialética, tanto investigação temática e a tematização estão ligadas à positividade do ser (a urdira "ficcional" que predica o ser ao Outro). Nesse movimento, educadores e educandos estão contextualizando e historicizando o que é ser para o Outro.

$3^{\circ}$ ) A problematização, a virada negativa na qual os envolvidos na jornada não apenas negam a visão mágica, mas a superam por uma visão crítica, partindo para a transformação do ser, não simplesmente limitado a um Outro opressor, mas que, a partir da mudança posição subjetiva ao Outro, possam construir possibilidades para ser mais.

Longe do "método Paulo Freire" ser uma "tentação romântica", crer que depois da tomada de conscientização, estudantes e educadores iniciaram uma esplendorosa luta, de modo a serem lembrados como A grande epopeia do Café Filipe, narrando grandes heróis proletários, conscientes de sua função histórica que lutaram bravamente pela emancipação da classe trabalhadora; ou, preferindo, uma estética modernista, um melodrama que narra a vida de opressão dos mocinhos (trabalhadores) agarrados à sua tradição cultural (grãos Filipe), sofrendo deveras nas mãos coercitivas do patronato local. Ao contrário do que muitos pensam, o "método freiriano" está ciente dos limites da prática educativa em relação à realidade. É "óbvio" que a abordagem freiriana dispõe de uma tensão (entre forma e conteúdo) revolucionária; no entanto, não rechaça as pequenas possibilidades que abrem margens para mudanças:

A preocupação com os limites da prática, no nosso caso da prática educativa como ato político, significa reconhecer, desde logo, que ela tem uma certa eficácia. Se não houvesse nada a fazer com a prática educativa, não haveria por que falar dos seus limites, da mesma forma como não haveria por que falar de seus limites se ela tudo pudesse. Falamos de seus limites precisamente porque, não sendo a alavanca da transformação profunda da sociedade a educação pode algo no sentido dessa transformação (FREIRE, 1993, p.28).

Podemos ler esse trecho de maneira dialética. Freire nos diz que os limites da práxis educacional estão friccionados aos limites do conteúdo da realidade social. Ora, se não houvesse limites do ato educacional à realidade, não haveria necessidade de uma educação crítica - as coisas se processariam em disposições naturais, e não em configurações humanas. A forma da educação crítica sinaliza aquilo que foi excluído do conteúdo hegemônico, e, ao sinalizar, poderá surtir reflexão, crítica e uma nova prática. Por exemplo, educadores progressistas podem ensinar competentemente os conteúdos, mas, "ao fazê-lo, se obrigam a desvelar o mundo da opressão (FREIRE, 1993, p.28)." Ao desvelar o conteúdo da opressão, a forma (método) aponta para os limites da prática educacional, relacionando-a aos limites de 
sua realidade, mas, os limites apontam para as possibilidades de mudanças, ou, pelas palavras de Freire: "Consciente dos limites de sua prática a professora progressista sabe que a questão que se coloca a ela não é a de esperar que as transformações radicais se realizem para que possa atuar. Sabe, pelo contrário, ter muito o que fazer para ajudar a própria transformação radical (FREIRE, 1993, p.28)."

A compreensão dos limites da prática política demanda, como ressaltou Freire (1993), o entendimento do político em relação a seu projeto. Em outras palavras, engajar na sintaxe popular não significa uma postura relativista nominalista e, sim, uma práxis que analisa os pontos divergentes sem, no entanto, esquecer o corte do Real; o "óbvio" não reconhecido pela educação bancária: o ato político.

Demanda que o educador assuma a politicidade de sua prática. Não basta dizer que a educação é um ato político assim como não basta dizer que o ato político é também educativo. É preciso assumir realmente a politicidade da educação. Não posso pensar-me progressista se entendo o espaço da escola como algo meio neutro, com pouco ou quase nada a ver com a luta de classes, em que os alunos são vistos apenas como aprendizes de certos objetos de conhecimento aos quais empresto um poder mágico. Não posso reconhecer os limites da prática educativo-política em que me envolvo se não sei, se não estou claro em face de a favor de quem a pratico. $\mathrm{O}$ a favor de quem pratico me situa num certo ângulo, que é de classe, em que divisa o contra quem pratico e, necessariamente, o porquê pratico, isto é, o próprio sonho, o tipo de sociedade de cuja invenção gostaria de participar (FREIRE, 1993, p.25).

Para um educador freiriano a política perpassa toda a esfera da vida humana, ou seja, até mesmo a ingênua mítica dos "grãos Filipe" está encharcada de ideologia. Contrária às leituras bancária, realista e nominalista que renegam a política, em um giro dialético, a própria ação de excluir o político, paradoxalmente, é uma decisão política. Logo, o "óbvio" que transparece diante de nossos olhos é que a política é esse Real incômodo do qual não conseguimos nos livrar. Sempre que tentamos formalmente excluir, mantermos as aparências de "apolítico", já estamos nos posicionando diante da realidade porque a epistemes das posições (bancária, realista, crítica, etc) inclui, em si mesma, um conteúdo político.

\section{A política}

O que essas perceptivas ignoram é o antagonismo, a luta inscrita no cerne da "coisa em si". Enquanto na explicação realista existe um conteúdo verdadeiro a ser descoberto (no nosso caso, o café e seus fenômenos), as diferentes lutas sobre o fenômeno do "Café Filipe" seriam simplesmente conceituais, conflitos se desencadeariam por leituras errôneas, equívocos sobre qual é o conteúdo verdadeiro. Na leitura nominalista, os conflitos decorrem de confusões epistemológicas; no entanto, o problema seria "superado" pela naturalização pacífica da pluralidade de ideias e significados sobre o fenômeno "Filipe".

A posição bancária organizaria o conflito separando as epistemologias e métodos de acordo com as necessidades de mercado. Seriam bem-vindas ciências e modelos educacionais que aumentassem a qualidade tanto da mão de obra, quanto de técnicas e maquinários que aumentem os índices de produtividade com os menores custos possíveis e, claro, diminuindo os conflitos sociais ${ }^{7}$. Em todos os casos, como diria Žižek (2017), a luta pela hegemonia (o

\footnotetext{
7 “Grãos Filipe" popularmente comum no século XX, hoje, possivelmente, não mais. Na crônica de Rita Elisa Seda (2009), publicada no jornal Vale Paraibano, narra-se, em tom romântico e nostálgico, uma referência aos "grãos Felipe". A cultura que marcou a infância da pequena Rita. Diz a autora, perdida em meio à vastidão verde do cafezal: "Onde encontro meu tesouro?" Na ânsia de encontrá-lo, no enorme terreiro, onde se coloca o café para secar, comenta a autora: "Revirei aqueles grãos com os olhos, depois foi com as mãos mesmo. E, nada de
} 
conteúdo particular que funciona com o substituto da universalidade do político) é infundada: "o Real derradeiro, a política, não pode ser fundamentada em nenhuma estrutura ontológica (ŽIŽEK, 2017, p.130)." Esta é razão pela qual Freire sempre se preocupou, primeiramente, em questionar qual é o objetivo político de determinado método educacional, se este está a favor de quem e do quê.

Do ponto de vista crítico é tão impossível negar a natureza política do processo educativo, quanto negar o caráter educativo do ato político. Isto não significa, porém, que a natureza política do processo educativo e o caráter educativo do ato político esgotem a compreensão daquele processo e deste ato. Isto significa ser impossível; de um lado, como já salientei, uma educação neutra, que se diga a serviço da humanidade, dos seres humanos em geral; de outro, uma prática política esvaziada de significação educativa. Neste sentido é que todo partido político é sempre educador e, como tal, sua proposta política vai ganhando cerne, ou não, na relação entre os atos de denunciar e de anunciar. Mas é neste sentido também que tanto no caso do processo educativo, quanto no do ato político, uma das questões fundamentais seja a clareza em torno de a favor de quem e do quê, portanto, contra quem e contra o quê, fazemos a educação e de a favor de quem e do quê, portanto, contra quem e contra o quê, desenvolvemos a atividade política. Quanto mais ganhamos esta clareza através da prática, tanto mais percebemos a impossibilidade de separar o inseparável: a educação da política. Entendemos então, facilmente, não ser possível pensar sequer a educação sem que se esteja atento à questão do poder (FREIRE, 1989, p. 15 a 16).

O "método Paulo Freire" opera na práxis de desvendar o sintoma da realidade social. Metodicamente educadores e educandos juntam forças para analisar tanto as contradições, quanto aquilo que foi excluído do método bancário. Aquilo que a educação bancária renega como político, ou seja, aquilo que ela exclui com força e violência de sua práxis educacional é próprio ao seu funcionamento político de realidade e está intrínseco à sua estrutura social. Os "grãos Filipe", nosso exemplo, fazem parte da cultura e da vida dos trabalhadores de café; logo, sob o ponto de vista bancário, são relações apolíticas.

No entanto, sob o ponto de vista da educação crítica, aquilo é considerado natural e passará por uma leitura a contrapelo, realidade, mitos, cultura, psiquismo, natureza humana etc., e é indagado de sua essência natural. Assim, a educação crítica vai além do semblante de naturalidade, indo ao encontro do conteúdo traumático político - aquilo que a educação bancária não quer saber. $\mathrm{O}$ que antes era apolítico agora se revela como relações hierárquicas de poder e constitui um conjunto de relações de subordinação e exclusão que, ao contrário de serem relações naturais, dependem excessivamente das relações políticas.

Devemos dizer que a educação crítica não pretende acabar como a sintaxe cultural dos "grãos Felipe". Longe de excluir essa bonita rede de relações sociais, esta pretende ir além da prática histórico-cultural, analisando suas inclinações repressivas e suas potencialidades emancipatórias. Como nos disse Kosik (1976), quando analisamos certo fenômeno, indagando e descrevendo suas características, devemos ter ciência que a "coisa em si" se manifesta naquele fenômeno e, ao mesmo tempo se esconde de nós. No entanto, devemos compreender o fenômeno em sua "totalidade" e em sua "essência". O movimento da dialética analisa os movimentos de determinado objeto em suas formas, no conteúdo, mas também naquilo que é excluído do conteúdo.

No caso dos "grãos Filipe", a "coisa em si" desse fenômeno está nas suas contradições latentes, em seu núcleo antagônico. Um educador crítico se preocuparia em analisar conteúdo

Filipe. Fiquei frustrada e perguntei a um dos agricultores se ainda existe o tal do Filipe. Ele me respondeu que os grãos antes de serem secados passavam pela enorme máquina de lavagem e ali os grãos Filipe eram desmembrados. Não ficava um Filipe inteiro." Por fim, o trabalhador diz: "Sabe dona... Eu tenho três filipes em casa, que eu levei para os meus filhos... apanhei no cafezal". 
das repressões inseridas por essa prática cultural, analisando os apegos e as exclusões ideológicas (os mecanismos "apolíticos" de opressão). Portanto, a prática cultural não morreria no processo dialético de aprender e ensinar, mas se transformaria, abrindo-se para potencialidades de ressignificação política. Antes de ver essa sintaxe cultural como um calmante da população local, algo que não deve ser tocado, como uma visão romântica da vida rural como bela, ingênua, afastada das contradições da vida urbana, deveríamos analisar o seu conteúdo estruturador e suas exclusões do político.

Juntos, professores e estudantes construirão críticas de sua própria cultura, pois a cultura é uma forma de leitura de mundo, e a educação freiriana é uma leitura crítica de mundo. Em poucas palavras, é um movimento de "negação da negação" (retroagir sua síntese) ao conteúdo da cultura, porque esta é uma coisa imediata, um costume que deve ser problematizado ${ }^{8}$. A educação freiriana "é um que-fazer pedagógico-político indicotomizável do que-fazer político-pedagógico, isso é, da ação política que envolve a organização dos grupos e das classes populares para intervir na reinvenção da sociedade". Lidar com a organização social é lidar com a pólis, o que não é "uma questão apenas técnica, mas, sobretudo, política" (FREIRE, 2000, p. 21).

Aprender e educar com as especificidades de determinado lugar, especificamente nosso exemplo didático dos "grãos Filipe", é contextualizá-lo às suas particularidades, não subestimando as capacidades dos sujeitos em sua realidade. Portanto, ao final do processo dialético de aprender e ensinar, o que ocorre não é uma exclusão da cultura popular; ao contrário, o que aparece são as "obviedades" excluídas, recalcadas pela cultura e pelo conteúdo educacional, ou seja, o método só consegue observar o óbvio, "a coisa em si", após o acontecimento, após a jornada do saber engajada pelos educandos e educadores. Ficamos tentados a utilizar a famosa frase de Hegel (2003), a coruja de Minerva levanta voo ao entardecer, como uma maneira de interpretar o poema de Freire (1971): "meus pés aprenderão o mistério dos caminhos, meus ouvidos ouvirão mais, meus olhos verão o que antes não viam enquanto esperarei por ti." Apenas no final do acontecimento, podemos retroagir e analisar seus limites e seus potenciais emancipatórios para as frestas da mudança. Por isso, também, sejamos educadores do "óbvio".

\section{Conclusão}

A dialética na educação é a revelação do "óbvio", o que significa dizer que o processo dialético tensiona a naturalidade hegemônica, quebrando o seu discurso estático, "socionatural", esclarecendo que seu semblante apolítico, no fundo, é político. Um educador

\footnotetext{
${ }^{8}$ Pelo ponto de vista dialético moderno (de Hegel a Marx), os entes dispõem de uma negação que não é simplesmente externa a si, mas interna, o que faz eles se movimentarem de maneira contraditória no tempo - ter história. No caso a cultura, esta se realiza tendo uma relação imediata do ser com o mundo. Para que haja a crítica do ser com seu mundo, deve haver certo distanciamento da imediatez da experiência vivida para a razão ("obvio" não conhecido), isto é, para pensar qual é sua condição no mundo (quem eu sou, qual é o meu lugar nas relações sociais e culturais) o ser deve tomar uma distância critica - aí que entra a educação crítica. No entanto, como assegura Eagleton (2000), a cultura não é uma simples alienação das experiências imediatas do sujeito, e nem uma vaga fantasia sem realização com o mundo, "mas um conjunto de potencialidades criadas pela história, que operam subversivamente dentro dela." Portanto a pergunta seria: "como libertar estas capacidades?" A reposta de Freire está na libertação da opressão, “a consciência é condicionada pela realidade, a conscientização é um esforço por meio da qual, ao analisar a prática que realizamos, percebemos em termos críticos o próprio condicionamento a que estamos submetidos (Freire, 1981, p.69)". Neste sentido, a aposta de Freire (1981) é tornar a cultura como um processo de transformação constante, não apenas contingente (a negatividade interna cultura), mas para-si, em relação com as demandas dos sujeitos, ou seja, no fundo, é tornar a cultura como uma revolução cultural. Uma "revolução cultural já conta com as novas bases materiais que viabilizam aquela negação. A nova cultura que nasce no seio da velha que é negada não está isenta, porém, de uma permanente análise crítica. É que a revolução cultural não é imobilista (idem, p.69)."
} 
das obviedades está disposto a argumentar e dialogar com seus educandos a assertiva que o mundo é movimento e transformação, e mais, que a realidade social é uma construção humana. Naquilo que o discurso hegemônico assegura e legitima como uma forma natural (seja social, cultural, econômica), é aí que o educador crítico se atenta ao conteúdo do discurso, e, na sua exclusão, o "em si”" político.

A literatura é sempre uma ferramenta interessante para pensarmos as "obviedades" não mediadas pela consciência. Um exemplo interessantíssimo de quebra de semblante está na parábola da "porta da lei", Diante da lei, Kafka (2011). O conto narra a história de um homem do campo que chega ao porteiro (o guarda da lei) e pede para entrar na porta da lei, que está aberta. O porteiro replica um não ao seu pedido. No entanto, o homem do campo pensa melhor e pergunta se ele pode entrar mais tarde. $\mathrm{O}$ porteiro afirma que sim, mas agora não. De porta aberta, o camponês não entra, mas se fascina para o que está dentro dela. $\mathrm{O}$ porteiro até dá-lhe uma banqueta e manda-o sentar ao pé da porta. O homem senta-se e espera por anos a aprovação de sua entrada, mas, esta nunca chega. Velho e quase para morrer, além de quase surdo e cego, indaga ao guardião da porta:

\footnotetext{
- Todos aspiram à lei - diz o homem. - Como se explica que em tantos anos ninguém além de mim pediu para entrar? O porteiro percebe que o homem já está no fim e, para ainda alcançar sua audição em declínio, ele berra: - Aqui ninguém mais podia ser admitido, pois esta entrada estava destinada só a você. Agora eu vou embora e fecho-a (KAFKA, 2011, p.106).
}

O pobre homem não se atentou a uma "simples" "obviedade" que era a de que a porta estava sempre aberta para ele. O infeliz acabou se preocupando demais com as diretrizes formais (regras, normas, fetichizando a lei dos homens). No entanto, não se atentou ao conteúdo, que a organização é uma construção humana e que tanto a porta, quanto o que está atrás dela, são semblantes, aparências dentro de aparências, não por elas serem falsas, mas, porque elas são a tecitura "ficcional" da realidade. A realidade não é um dado natural, apolítico, mas uma construção político-social. Talvez esta seja a grande lição da educação como práxis crítica: dialogar e ensinar aos educandos que a porta não está apenas aberta, mas que foi construída por mãos humanas.

\section{Referências}

ANAXIMANDRO, PARMÊNIDES E HERÁCLITO. Os Pensadores Originários. Tradução de Emmanuel Carneiro Leão e Sergio Wrublewski. Petrópolis: Vozes, 1990.

EAGLETON, Terry. A idéia de cultura. Trad. Sandra Castello Branco. São Paulo: Unesp, 2005.

FREIRE, Paulo. Ação cultural para a liberdade. 5. ed. Rio de Janeiro: Paz e Terra. 1981.

FREIRE, Paulo. Educação: o sonho possível. In: BRANDÃO, C.R. (Org.). O educador: vida e morte. Rio de Janeiro: Edições Graal, 1985.

FREIRE, Paulo. Pedagogia do oprimido. 17. Ed. Rio de Janeiro, Paz e Terra, 1987.

FREIRE, Paulo. A Importância do ato de ler. Cortez Editora. São Paulo, 1989. 
FREIRE, Paulo. Pedagogia da indignação: cartas pedagógicas e outros escritos. Editora Unesp. São Paulo, 2000.

FREIRE, Paulo. Política e educação: ensaios. 5. ed. São Paulo, Cortez, 2001 (Coleção Questões de Nossa Época; v.23).

FREIRE, Paulo. Pedagogia da autonomia: saberes necessários à prática educativa. São Paulo: Paz e Terra, 2002.

GADOTTI, Moacir (Org.). Paulo Freire: Uma biobibliografia. Cortez Editora, São Paulo, 1996.

HEGEL, Friedrich. Princípios da filosofia de direito. São Paulo: Martins Fontes, 2003.

KAFKA, Franz. Essencial Franz Kafka. São Paulo, Penguin, 2011.

KOSIK, Karel. Dialética do concreto. Tradução de Célia Neves e Alderico Toríbio, 2. ed. Rio de Janeiro, Paz e Terra, 1976.

SEDA, Rita Elisa. Grão de Filipe. Jornal Valeparaibano, São José do Rio Preto. 28 de maio de 2009. Disponível em: https://palavrasdeseda.blogspot.com/2009/05/grao-de-fillipe.html. Acesso em: 3 jul. 2021.

SKINNER, Quentin. Language and Social Change. In: TULLY, James (org.). Meaning and Context: Quentin Skinner and His Critics. Oxford, Polity Press, 1988. p.03-27

ŽIŽEK, Slavoj.O mais sublime dos histéricos: Hegel com Lacan. Rio de Janeiro: Editora Zahar, 1991.

ŽIŽEK, Slavoj. Vivendo no fim dos tempos. Tradução Maria Beatriz de Medina. São Paulo: Boitempo, 2012.

ŽIŽEK, Slavoj. Menos que nada: Hegel e a sombra do materialismo dialético. São Paulo: Boitempo, 2013.

ŽIŽEK, Slavoj. O sujeito incômodo: o centro ausente da ontologia política; tradução Luigi Barichello. São Paulo: Boitempo, 2017. 